\title{
MICROBIOLOGICAL CONTAMINATION OF SOME FRESH LEAFY VEGETABLES SOLD IN CAPE COAST, GHANA
}

\author{
L. Yafetto*, E. Ekloh, B. Sarsah, E. K. Amenumey And E. H. Adator \\ (L. Y., E. E. \& B. S.: Department of Molecular Biology and Biotechnology, School of Bio- \\ logical Sciences, College of Agriculture and Natural Sciences, University of Cape Coast, \\ Cape Coast, Ghana; E. K. A.: Department of Hospitality and Tourism Management, Col- \\ lege of Humanities and Legal Studies, University of Cape Coast, Cape Coast, Ghana; E. \\ H. A.: Department of Food and Human Nutritional Sciences, Faculty of Agricultural and \\ Food Sciences, University of Manitoba, Winnipeg, MB R3T 2N2, Canada). \\ *Corresponding author's email: lyafetto@ucc.edu.gh
}

\begin{abstract}
This study evaluated the microbiological contamination of cabbage, lettuce, and scallions sold in Abura and Kotokuraba markets in Cape Coast, Ghana. These vegetables were analyzed for the presence and levels of microorganisms using standard microbiological procedures. Results revealed bacterial and fungal contaminations of the vegetables from Abura and Kotokuraba markets. Mean bacterial counts recorded in Nutrient Agar, for example, from Kotokuraba market were $1.93 \times 10^{8}, 1.23 \times 10^{8}$, and $1.17 \times 10^{8} \mathrm{cfu} / \mathrm{ml}$ for cabbage, lettuce and scallion, respectively, higher than mean bacterial counts recorded from Abura market at 9.9x107, 2.8x10 $0^{7}$, and $6.60 \times 10^{7} \mathrm{cfu} / \mathrm{ml}$ for cabbage, lettuce and scallion, respectively. Conversely, the mean fungal counts for cabbage, lettuce and scallion were higher at Abura market than Kotokuraba market. Bacteria isolated from the vegetables include Escherichia coli, Enterobacter spp., Klebsiella spp., Salmonella spp., Serratia marcescens, and Staphylococcus, whereas fungi of the genera Aspergillus, Candida, Fusarium, Penicillium, and Rhodotorula were isolated. These results indicate that the vegetables are significantly contaminated, and have poor microbiological quality that could potentially result in outbreak of foodborne illnesses. Contaminations of the vegetables were due to poor pre- and post-harvest handling practices. The implications of findings of this study on tourism and hospitality industries in Cape Coast are discussed.
\end{abstract}

Keywords: cabbage, food microbiology, foodborne microorganisms, Ghana, lettuce, scallion

\section{Introduction}

Vegetables remain one of the most important portions of a balanced diet, because of the many attendant nutritional benefits that inure to their consumption. Vegetables are rich dietary sources of micronutrients, minerals, vitamins and, most importantly, antioxidants and fibre, all of which are vital to human health, wellbeing and disease prevention (Eni et al., 2010). Overall public awareness of healthy eating habits has been intensified, prompting an increasing demand and incorporation of fresh vegetables in diets, especially because of their convenience, freshness, taste and health 
benefits (Olaimat \& Holley, 2012). The Food and Agriculture Organization and the World Health Organization strongly recommend more than $400 \mathrm{~g} /$ day intake of fruits and vegetables in diets to promote good health (FAO/ WHO, 2014).

Despite the health benefits derived from consuming fresh vegetables, the risk of microbiological contaminations in vegetables is of public concern due to the possibility of vegetable contaminations along the food chain, beginning from the vegetable farm to the dinner table (Kuan et al., 2017); this concern is compounded by the fact that these vegetables are mostly eaten fresh (not cooked) and washing may not guarantee decontamination, so that any resident microorganism easily enter the alimentary canal. Thus, these public concerns are justifiably informed based on reported cases of numerous foodborne disease outbreaks caused by consumption of fresh vegetables contaminated by microorganisms like Listeria monocytogenes, Escherichia coli O157:H7, and Salmonella spp (CDC, 2011 \& 2012; Maffei et al., 2013; Beuchat 2017). Various estimates of incidences of foodborne disease outbreaks have resulted in illnesses, hospitalizations, deaths, and even food recalls in some countries, particularly United States of America (Scallan et al., 2011; WHO, 2015; CDC, 2016).

Microbiological contamination of vegetables can occur directly or indirectly through (i) contact with soil, dust, water, and (ii) punctures and open cuts of tissues of vegetables; thus, contaminations of vegetables may occur internally or externally during cultivation, harvest, packaging, storage, transporting and marketing (Solomon et al., 2002; Bernstein, 2007; Eni et al., 2010; de Giusti et al., 2010). Contaminated vegetables rot more quickly and become unwholesome due to microbiological activities of resident microorganisms. Vegetable spoilage by microorganisms is possible, because vegetables serve as suitable substrates that present the microorganisms with a plethora of valuable nutrients essential for microbial growth. This is a concern for consumers and public health and safety practitioners. Vegetables, whether sold as part of street-vended foods, as part of the menu at eateries, or used domestically for family meals, have understandably come under strict scrutiny by the Ghanaian vegetable consumers. This is particularly so since there is widespread belief and acknowledgement among most consumers that vegetables sold on the Ghanaian markets are largely produced and handled under unhygienic conditions and practices, i.e., application of manure to soils during cultivation of vegetables, irrigation of vegetables farms with heavily contaminated water, use of unclean water to wash vegetables, dressing vegetables on the bare floor and concrete slabs on the farm and at the grocery, and insufficient pre- and post-harvest inspections of vegetables (Wachtel et al., 2002a \& 2002b). In Ghana, pipe-borne water is the most commonly used water source to irrigate vegetable farms, but due to the high cost and unreliable water supply, most vegetable farmers have resorted to the use of water from streams, wells and storm drains as alternate water sources to irrigate vegetable farms. Unfortunately, these alternative water sources are heavily polluted, especially with pathogenic and toxigenic microorganisms (Keraita et al., 2008; Donkor et al., 2010; Adentunde et al., 2015).

Some studies in Ghana suggest that vegetables sold at the groceries in the markets are contaminated with microorganisms, mostly bacteria (Mensah et al., 2001; Obeng at al., 2007; Keraita et al., 2008; Donkor et al., 2009 \& 2010; Amoah, 2014; Adentunde et al., 
2015; Abakari et al., 2018). Findings of these studies motivated the need to evaluate the microbiological quality of fresh, leafy salad vegetables that are usually not cooked, but are consumed raw. The present study, therefore, aimed to investigate the microbiological contaminations of cabbage, lettuce, and scallions sold in two markets in Cape Coast, Ghana. The significance of this study stems from the fact that Cape Coast, capital of the Central Region of Ghana, accounted for over $41 \%$ of tourist visits to Ghana for the period $2015-2018$. This is not surprising given that the Central Region hosts what is called the "big three" of Ghana's tourist attractions - Kakum National Park, Cape Coast Castle, and Elmina Castle. Thus, the outbreak of any foodborne disease may have grave implications for not only citizens, but also tourists. In addition, and equally important, the University of Cape Coast hosts a significant number of international student population that may be susceptible to such potential outbreaks of foodborne diseases. We present the findings of this study, recommend strategies for improving wholesomeness of vegetables before consumption, and discuss the implications of the findings to the tourism and hospitality industries in Cape Coast, Ghana.

\section{Sample collection}

\section{Experimental}

A headed cabbage (Brassica oleracea var. capitata L.), a bunch of loose-leaf lettuce (Lactuca sativa) and a bundle of scallions (Allium fistulosum) were purchased from three randomly selected groceries (named A, B, and C) each at Abura and Kotokuraba markets in Cape Coast. The vegetables were separately packaged in sterile zip-locks, placed on ice in an ice chest, and immediately transported to the laboratory for microbiological analyses using standard microbiological procedures. We in- terviewed the vegetable vendors at the selected groceries with regards to pre- and post-harvest handling practices during transportation of vegetables to the groceries. Also, observations such as washing of vegetables before sale, frequent cleaning of benches, weighing scales and knives, use of aprons, wearing of hair coverings, proper handling of money, use of gloves while serving, etc. were made during purchase. We also interacted with the selected vegetable vendors about hygienic conditions and handling of vegetables at their groceries.

\section{Study area}

The study was conducted in Cape Coast $\left(5^{\circ}\right.$ 7'53.44" North, $1^{\circ} 16^{\prime} 53.11^{\prime \prime}$ West) in Ghana. Cape Coast has a population of 169,894 (Yafetto et al., 2019). Most of the residents engage in economic activities such as farming, fishing and petty trading, and the Metropolis, over the last decade, has demonstrated the market potential for local produce and manufactured goods for agriculture and commerce sectors from other parts of Ghana. In addition to its market potential, Cape Coast is a historic, popular tourism destination for both domestic and foreign tourists, and it continues to enjoy an enviable status as one of the most important tourism destinations in Ghana (Ghana Statistical Service, 2010). There a number of markets located within Cape Coast, popular amongst them are the Abura and Kotokuraba markets, from which samples were obtained for this study. Although both markets are located in the populous communities, Abura is a suburb located at the Cape Coast North Constituency, whereas Kotokuraba is located at the Cape Coast South Constituency. Specifically, Abura market is a relatively small market that serves suburbs like Adisadel, Akotokyir, Kakumdo, Pedu, the Cape Coast Technical University and the University of Cape Coast; Kotokuraba 
market, on the other hand, is a larger, ultra- the suburbs in Cape Coast (Fig. 1). modern central market that serves almost all

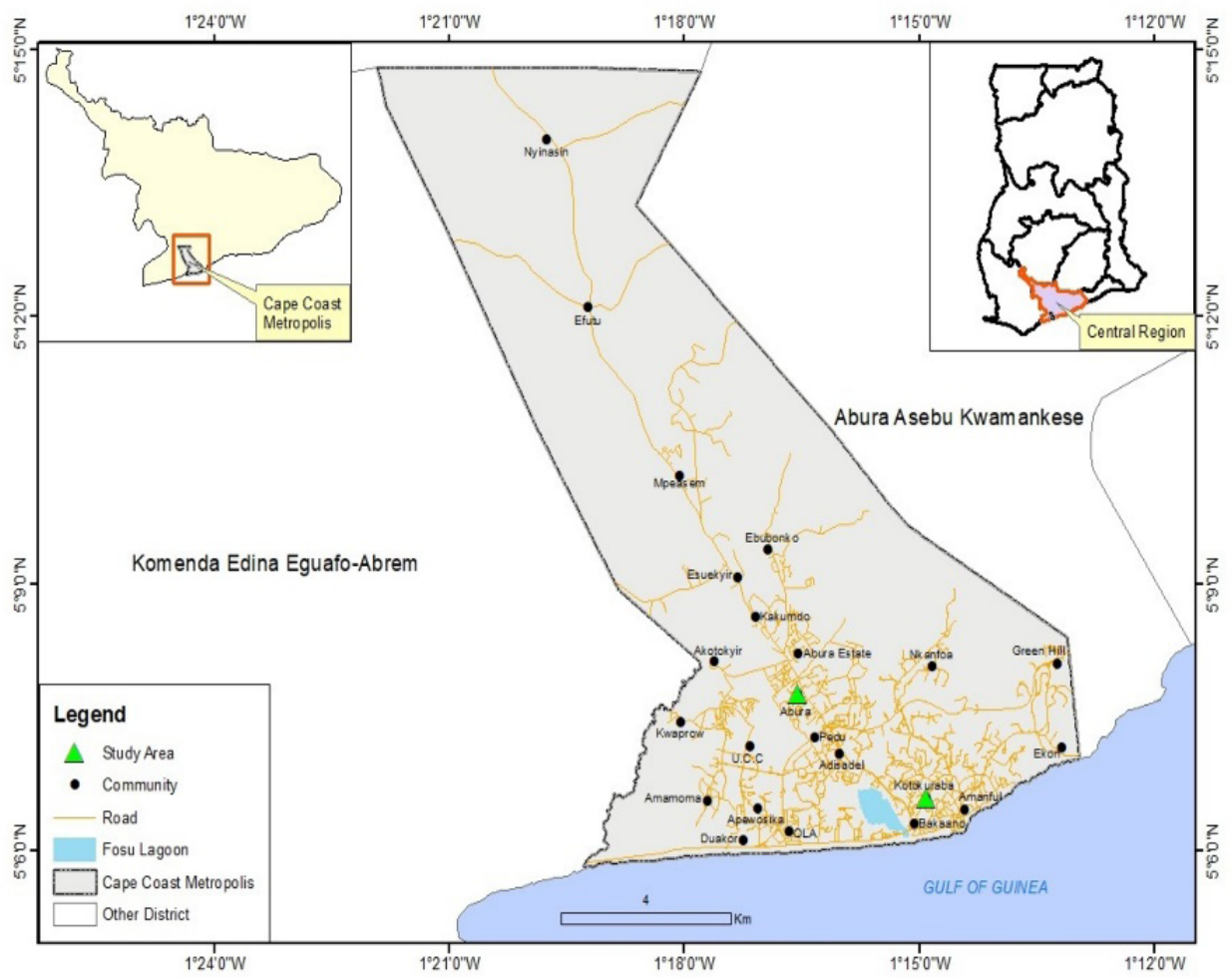

Fig. 1: Cape Coast Metropolis indicating two suburbs, Abura and Kotokuraba, where vegetables were obtained for the study. Source: Richard Adade, Centre for Coastal Management, University of Cape Coast, Cape Coast, Ghana.

\section{Culture media}

MacConkey Agar (MAC), Nutrient Agar (NA), and Potato Dextrose Agar (PDA) media (Oxoid Ltd., England) used in this study were prepared according to the manufacturer's instructions. The media were sterilized at a pressure of $1.1 \mathrm{~kg} / \mathrm{cm}^{2}$ at $121^{\circ} \mathrm{C}$ for $15 \mathrm{~min}-$ utes using an autoclave (Shimadzu KY-23D, Omron Corporation, Japan). MAC and NA media were used to isolate bacteria, whereas PDA medium was used to isolate fungi from the vegetables.

\section{Stock Solutions from Vegetables}

Stock solutions from vegetables were prepared based on method described by Yafetto et al. (2019). Ten grams of leaves from the headed cabbage were weighed and placed in a $200 \mathrm{ml}$ conical flask, after which $90 \mathrm{ml}$ sterile $0.1 \%$ peptone water (the diluent) was added. The cabbage leaves and diluent were gently, but thoroughly vortexed on a platform shaker (Scientific Industries, Inc., USA) for 5 minutes to extricate any microbe that may be resident on the surface of the cabbage leaves. The dilu- 
ent was decanted and used as a stock solution to prepare serial dilutions for microbiological analyses. Serially diluted stock solution of dilution factor $10^{-3}$ was used for fungal isolation, while a $10^{-6}$ dilution was used for bacterial isolation. The same procedure and dilutions were repeated for the preparation of stock solutions from lettuce and scallions.

\section{Isolation of microbes}

To isolate fungi, $1 \mathrm{ml}$ aliquot $\left(10^{-3}\right.$ dilution) of stock solution of cabbage leaves was dispensed into a Petri dish. Twenty milliliters of molten, but cooled PDA medium was added and evenly mixed with the stock solution. The culture plates were prepared in triplicates for cabbage from each of the three randomly selected vendors from a market (i.e., $n=9$ ). The culture plates were allowed to solidify and incubated at $25^{\circ} \mathrm{C}$ for 7 days in an incubator (Plus II, Gallenkamp, England). This isolation procedure was repeated for the microbiological analyses of lettuce and scallions from the two markets.

Bacteria were isolated with the same procedure used to isolate fungi, except that $1 \mathrm{ml}$ aliquot of stock solution with a dilution factor $10^{-6}$ was dispensed separately into $20 \mathrm{ml} \mathrm{mol-}$ ten MacConkey agar and $20 \mathrm{ml}$ molten nutrient agar. The culture plates were prepared in triplicates for cabbage from each of the three randomly selected vendors from a market (i.e., $\mathrm{n}=9$ ). The plates were then allowed to solidify and incubated at $37^{\circ} \mathrm{C}$ for 2 days. This isolation procedure was repeated for the microbiological analyses of lettuce and scallions from the two markets.

\section{Identification of isolated fungi}

Fungi isolated from cabbage, lettuce and scallions were identified according to the procedure described by Yafetto et al. (2019).
A small amount of fungal mycelium was removed from a fungal colony, immersed in a drop of $70 \%$ of alcohol on a glass slide, after which it was gently teased out with the inoculation needle. A drop of lactophenol cotton blue dye was added to the mycelium and gently covered with a glass coverslip. Excess dye was removed from the prepared fungal specimen with a Whatman filter paper (Sigma-Aldrich, USA), which was then observed under the microscope. Microscopic identifications of fungi were determined based on morphological and growth features using Leica DM500 Compound Microscope (Leica Microsystems, Switzerland) in consultations with the relevant identification manuals (Davet \& Rouxel, 2000; Ellis et al., 2007; Pitt \& Hocking, 2009; Watanabe, 2010; Campbell et al., 2013; Kidd et al., 2016).

\section{Identification of isolated bacteria}

Sterilized platinum inoculation loops (Thomas Scientific, New Jersey, USA) were used to streak isolated bacteria on MAC and NA to obtain pure bacterial sub-cultures, after which they were incubated at $37^{\circ} \mathrm{C}$ for 24 hours. Identities of bacteria cultures were confirmed using morphological characteristics, and citrate and catalase standard biochemical tests (Cowan et al., 1993; Cheesbrough, 2006). Images of fungal and bacterial cultures were captured with an in-built, 8 megapixels' digital camera of Infinix NOTE 4 cellphone (Model X572, China).

\section{Colony counts and statistical analyses}

Bacterial and fungal colonies were enumerated with digital colony counter (Stuart Scientific, UK), and expressed as mean colony forming units per $\mathrm{ml}(\mathrm{cfu} / \mathrm{ml})$ and mean $\log _{10} \mathrm{cfu} /$ $\mathrm{ml}$ ( \pm Standard Error), where $\mathrm{n}=9$. Differences in the means were statistically analyzed using ANOVA at confidence level of $95 \%(\mathrm{p} \leq 0.05)$. 


\section{Results and Discussion}

Bacterial and fungal contaminations of cabbage, lettuce and scallions

This study evaluated the microbiological quality of cabbage, lettuce and scallions sold in Cape Coast, Ghana. Significantly high means of bacterial counts were observed in cabbage, lettuce and scallion from both Kotokuraba and Abura markets than fungi (Tables 1 and 2). Interestingly, mean fungal counts for cabbage, lettuce and scallions were higher at Abura market than at Kotokuraba market (Tables 1 and 2). Most bacteria isolated and the high levels of microbial contaminations reported for cabbage, lettuce and scallions in this study are similar to findings previously reported for other studies both in Ghana and elsewhere (Adebolu \& Ifesan, 2001; Mensah et al., 2001; Wachtel et al., 2002a,b; Omemu \& Bankole, 2005; Tambekar \& Mundhada, 2006; Olayemi 2007; Donkor et al., 2009; Uzeh et al., 2009; Donkor et al., 2010; Eni et al. 2010; Yeboah-Manu et al., 2010; Annan-Prah et al., 2011; Goja \& Mahmoud, 2013; Maffei et al., 2013; Buyukunal, 2015; Kuan et al., 2017; Yeleliere et al., 2017; Abakari et al., 2018). Results of bacterial and fungal colony counts of cabbage, lettuce and scallions in this study are presented graphically as mean $\log _{10} \mathrm{cfu} / \mathrm{ml}$ (Figs. 2 and 3). Despite the high microbial contaminations reported in this study, it is important to note that none of the vegetables showed any visible sign of spoilage. However, spoilage of vegetables could occur if not properly washed before stored (Center for Food Safety, 2014). Eni et al. (2010) reported that bacterial contamination of vegetables decreased significantly when vegetables were washed with increasing concentrations of vinegar. This suggests that the dire consequence of disease outbreaks that usually occurs as a result of the consumption of contaminated vegetables can be effectively managed, if vegetables are properly handled with prudent washing regimen.

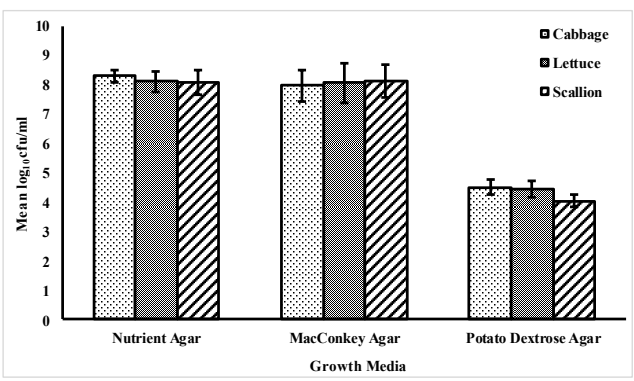

Fig. 2: Mean $\log _{10} \mathrm{cfu} / \mathrm{ml}$ of bacteria and fungi isolated from cabbage, lettuce and scallion from Kotokuraba market.

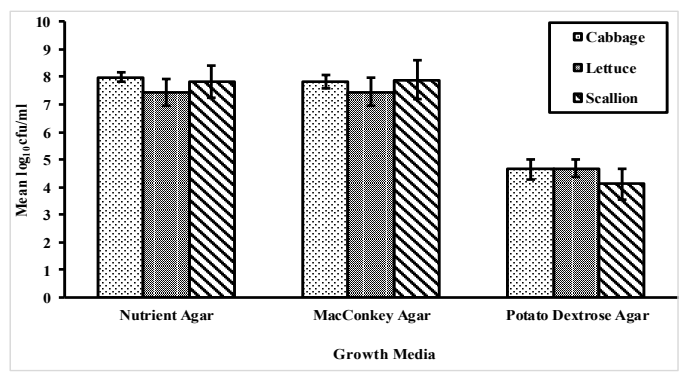

Fig. 3: Mean $\log _{10} \mathrm{cfu} / \mathrm{ml}$ of bacteria and fungi isolated from cabbage, lettuce and scallion from Abura market.

Bacteria and fungi isolated from vegetables

The selected vegetables evaluated in this study were contaminated with bacteria and fungi (Fig. 4). Bacteria that had contaminated the vegetables were Enterobacter spp., Escherichia coli, Klebsiella spp., Salmonella spp., Serratia marcescens and Staphylococcus. E. coli, Salmonella spp., and Staphylococcus spp. possibly originated from irrigated water contaminated with faecal matter. Eni et al. (2010) isolated similar bacteria in their study. E. coli, and Salmonella spp. have been 
particularly implicated in foodborne disease outbreaks associated with consumption of vegetables (Beuchat, 2002; Sivapalasingam et al., 2004; CDC, 2011 \& 2012; Maffei et al., 2013). Isolation of these bacteria from vegetables evaluated in this study should raise food safety concerns among consumers, vendors, vegetable farmers, tourists, and health authorities, because of their implications in global foodborne disease outbreaks (Beuchat, 2002; Sivapalasingam, 2004; CDC, 2011, 2012; Scallan et al., 2011; Maffei et al., 2013). Compared to the guidelines of the Health Protection Agency (2009) and Center for Food Safety (2014), based on the mean colony counts reported for this study, it is obvious that the extent of microbiological contamination of the vegetables from the two markets is high (Tables 1 and 2). This suggests that most of the vegetables sold in Cape Coast may be unwholesome for consumption, so that food safety concerns among consumers in the Metropolis is understandable.

Curiously, Serratia marcescens, a pink-pigmented Gram-negative bacterium of the family Enterobacteriaceae shown in Fig. 4 , was isolated from scallion from both markets, and from lettuce from Kotokuraba market only. Surprisingly, S. marcescens was not isolated from cabbage from both markets (Table 3). Serratia marcescens is an opportunistic pathogen that can be isolated from water, soil, plants, air, insects, and other animals: it has the ability to colonize and survive on materials such as hospital instruments and farm equipment; it is involved in food spoilage and can cause serious diseases, that can sometimes be fatal, in humans (Rafii, 2014); and it is associated with urinary and respiratory infections, endocarditis, osteomyelitis, septicemia, wound infections, eye infections and meningitis (Buckle, 2016). From findings earlier reported in studies in Ghana on microbiological qualities of vegetables, our isolation of $S$. marcescens from lettuce and scallion in this study is likely the first report of its presence on any vegetable sold on the Ghanaian market. This finding is critical, because Serratia spp. as opportunistic pathogens, may be widespread on vegetables sold in Cape Coast, and their presence on these vegetables poses serious food safety concern. This situation is worsened considering the detection of the aforementioned pathogenic and toxigenic bacteria in this study (Fig 4). Serratia marcescens, has however been reported on some vegetables in other studies elsewhere (Falomir et al., 2010; Sikora et al., 2012; Akoachere et al., 2018).

Fungi isolated and confirmed from the vegetables are of the genera Aspergillus, Candida, Fusarium, Penicillium, and Rhodotorula (Fig. 4). Annan-Prah et al. (2011) reported fungal contaminations of street-vended foods in Cape Coast including ready-to-eat salads that served as accompaniment to mainly rice dishes. Combined fungal and bacterial activities often lead to deterioration and eventual spoilage of vegetables, making them unwholesome for consumption and potential sources of foodborne illnesses.

TABLE 1

Mean microbial counts of leafy vegetables obtained from Kotokuraba market, Cape Coast, Ghana

\begin{tabular}{llll}
\hline & \multicolumn{3}{l}{ Mean bacterial and fungal counts $(\mathbf{c f u} / \mathbf{m l}) ; \mathbf{n}=\mathbf{9}$} \\
\cline { 2 - 4 } Culture medium & Cabbage & Lettuce & Scallions \\
\hline Nutrient Agar & $1.93 \times 10^{8}$ & $1.23 \times 10^{8}$ & $1.17 \times 10^{8}$ \\
MacConkey Agar & $9.40 \times 10^{7}$ & $1.16 \times 10^{8}$ & $1.36 \times 10^{8}$ \\
Potato Dextrose Agar & $3.10 \times 10^{4}$ & $2.90 \times 10^{4}$ & $1.10 \times 10^{4}$ \\
\hline
\end{tabular}




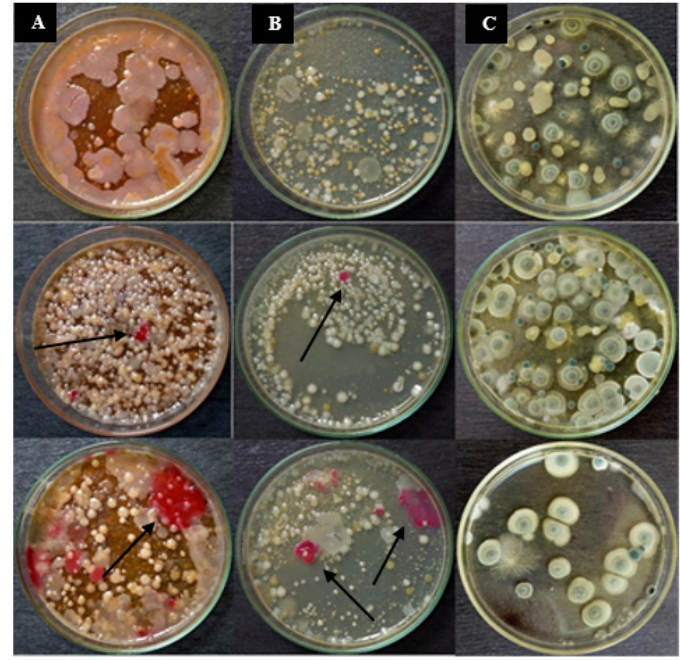

Fig. 4: Bacteria and fungi isolated from cabbage (Top Row), lettuce (Middle Row), and scallion (Bottom Row) on MacConkey Agar medium (column A), Nutrient Agar medium (column B), and Potato Dextrose Agar medium (column C). Pink-pigmented bacterium, Serratia marcescens, isolated from lettuce and scallion (Arrowed).

TABLE 2

Mean microbial counts of leafy vegetables obtained from Abura market, Cape Coast, Ghana.

\begin{tabular}{|c|c|c|c|}
\hline \multirow[b]{2}{*}{ Culture medium } & \multicolumn{3}{|c|}{ Mean bacterial and fungal counts $(\mathrm{cfu} / \mathrm{ml}) ; \mathrm{n}=9$} \\
\hline & Cabbage & Lettuce & Scallions \\
\hline Nutrient Agar & $9.90 \times 10^{7}$ & $2.80 \times 10^{7}$ & $6.60 \times 10^{7}$ \\
\hline MacConkey Agar & $6.80 \times 10^{7}$ & $2.90 \times 10^{7}$ & $7.80 \times 10^{7}$ \\
\hline Potato Dextrose Agar & $4.50 \times 10^{4}$ & $4.70 \times 10^{4}$ & $1.30 \times 10^{4}$ \\
\hline
\end{tabular}

Sources of Microbial Contamination of Vegetables

Bacteria and fungi present on vegetables may be the natural flora of the vegetables. However, the presence of these bacteria and fungi on the vegetables may be attributed to some cultivation practices, including irrigation of vegetable farms with contaminated water, application of animal wastes as manure to enrich the soil, preand post-harvest handling practices, transportation, storage and processing (Ray \& Bhunia, 2007; Ofor et al., 2009; Eni et al., 2010). It is well established that most vegetable farmers in Ghana commonly use pipe-borne water, vis $a$ $v i s$, water from streams, wells and storm drains to irrigate their vegetable farms. Microorganisms detected in this study are reported also in other studies where water from streams, wells and storm drains were confirmed to have been contaminated with similar microorganisms (Keraita et al., 2008; Donkor et al., 2009; Donkor et al., 2010; Adentunde et al., 2015; Abakari et al., 2018; Akoachere et al., 2018). Our observations and interactions with the 
selected vegetable vendors during this study confirmed that vegetables are generally poorly handled when they are offloaded from vehicles that had transported them from the vegetable farms and at the groceries by the vendors. This poor, unhygienic handling of vegetables is similar to those observed for beef and chevon by Yafetto et al. (2019).

TABLE 3

Isolation of Serratia marcescens from vegetables; + (Present); - (Absent) Presence and absence of Serratia marcescens

\begin{tabular}{llllllll}
\hline & \multicolumn{6}{l}{ Presence and absence of Serratia marcescens } \\
\cline { 2 - 7 } Grocery & Abura market & Lettuce & Scallions & Cabbage & Lettuce & Scallions \\
\cline { 2 - 7 } & Cabbage & Letokuraba market & + \\
\hline A & - & - & - & - & - & + \\
B & - & - & + & - & + & + \\
C & - & - & + & - & + \\
\hline
\end{tabular}

Implications of Study on Tourism and Hospitality Industries in Cape Coast, Ghana

Food consumed by visitors and tourists is one of the main facilitating factors of the tourism product in a destination. In some destinations, food is the core product and reason for travel. The extent of microbiological contaminations in the food chain, therefore, is a public health concern, especially for a town that has a significant traveler population. In the least, one would expect cases of traveler's diarrhoea, which can disrupt travel plans, in addition to the discomfort caused to the victims. In serious cases, ingestion of contaminated foods can lead to hospitalization or even death. In the present social media era and connected communities, the outbreak of any such cases of foodborne diseases has far-reaching and almost instantaneous implications for destination marketing. Cape Coast and its tourism industry stand to lose a lot if measures are not put in place to improve food handling practices to reduce the level of contaminations in the food chain.

Tourists' perceptions of risks of food safety would influence choice of visiting Cape Coast or not, and, even when they do visit, what and where they eat are greatly influenced by such perceptions. Given that most of these vegeta- bles are produce of residents in and around the region, outbreaks of foodborne diseases would negatively affect demand for the produce by local farmers, and consequently the distribution of income and benefits from tourism to surrounding local communities.

\section{Recommendations}

We recommend that (i) vegetable farmers employ the use of pipe-borne water, instead of water from streams, wells, and storm drains to irrigate their vegetables, and observe good pre- and post-harvest handling practices of vegetables; (ii) vendors should equally observe good personal and environmental hygienic practices at the groceries; (iii) sellers of street-vended foods and consumers must thoroughly wash vegetables before sale and consumption; and (iv) the Food and Drugs Authority, Ghana Standards Authority, Ghana Health Service, Ghana Tourism Authority and National Commission for Civic Education must embark on public education in relation to good agronomic and food handling practices, and strictly enforce compliance to food quality standards at all markets in Cape Coast, Ghana. Future research should be conducted to investigate antimicrobial susceptibility of bacteria isolated from vegetables. 


\section{Conclusion}

We conclude, based on findings from this study that, (i) microbial contaminations of vegetables evaluated are high, (ii) cabbage, lettuce and scallions sold in markets in Cape Coast, Ghana, are contaminated with bacteria and fungi, (iii) bacterial contaminations of the vegetables are higher than fungal contaminations, and (iv) poor, unhygienic pre- and post-harvest handling of vegetables contribute significantly to contaminations of vegetables. The microorganisms isolated from the vegetables may be pathogenic and/or toxigenic, with the potential of causing foodborne illnesses to consumers. This study provides further impetus to thoroughly investigate the microbiological quality of all kinds of food, whether cooked or raw, to elucidate the extent of food safety risks associated with microbial contaminations of fruits, vegetables, cooked street-vended foods and foods on the menus of restaurants in Cape Coast, Ghana.

\section{Acknowledgements}

We express our gratitude to Patience Karbo, and Messrs Solomon Mensah and George Koomson, Department of Molecular Biology and Biotechnology, University of Cape Coast, Ghana, for providing technical assistance during the study. Many thanks to Mr. Richard Adade, Centre for Coastal Management, University of Cape Coast, Ghana for providing the map of Cape Coast. We are grateful also to the selected vegetable vendors for providing additional information about hygienic practices at their groceries during the study.
References
Abakari, G., Cobbina, S. J. \& Yeleliere, E. (2018) Microbial quality of ready-to-eat vegetable salads vended in the central business district of Tamale, Ghana. International Journal of Food Contamination 5, 1 - 9 .

Adebolu, T. T. \& Ifesan, B. O. (2001) Bacteriological quality of vegetables used in salads. Nigerian Journal of Microbiology 15 (1), 81 - 85.

Adetunde, L. A., Sackey, I., Dombirl, D. D. \& MariAMA, Z. W. (2015) Potential links between irrigation water microbial quality and fresh vegetables quality in Upper East Region of Ghana subsistence farming. Annual Research and Review in Biology 6 (6), 347 - 354.

Akoachere, J-F. T. K., Tatsinkou, B. F. \& Nkengfack, J. M. (2018) Bacterial and parasitic contaminants of salad vegetables sold in markets in Fako Division, Cameroon and evaluation of hygiene and handling practices of vendors. MBC Research Notes 11, 100.

Амодн, D. (2014) Microbial risks assessment of mixed vegetable salads from selected canteens in the Kumasi Metropolis, Ghana. Master's Thesis, Department of Food Science and Technology. Kwame Nkrumah University of Science and Technology. pp $41-56$.

Annan-Prah, A., Ameworwor, D. H. A. K., Osei-Kofi, J., AMOONo, S. E., AKorli, S. Y.,

SAKA, E. \& NDADI, H. A. (2011) Street foods: handling, hygiene and client expectations in a World Heritage Site Town, Cape Coast, Ghana. African Journal of Microbiology Research 5 (13), $1629-1634$.

Bernstein, N., Sela S. \& Neder-Lavon, S. (2017) Assessment of contamination potential of lettuce by Salmonella enterica Newport added to the plant growing medium. Journal of Food Protection 70, 1717 - 1722 .

Beuchat, L. R. (2002) Ecological factors influencing survival and growth of human pathogens on 
raw fruits and vegetables. Microbes and Infection 4, $413-423$.

Buckle, J. (2016) Clinical Aromatherapy: Essential Oils in Healthcare. 3rd ed. UK. Elsevier Ltd. pp. $130-167$.

Buyukunal, S. K., Issa, G., Aksu, F. \& Vural, A. ( 2015) Microbiological quality of fresh vegetables and fruits collected from supermarkets in Istanbul, Turkey. Journal of Food and Nutrition Sciences 3 (4), 152 - 159. doi: 10.11648/j. jfns.20150304.13

Campbell, C. K., Johnson, E. M. \& Warnock, D. W. (2013) Identification of Pathogenic Fungi. 2nd ed. London, UK: Wiley-Blackwell.

CENTER FOR FOOD SAFETY. (2014) Microbiological Guidelines for food: For ready-to-eat food in general and specific food items. Revised Edition; August 2014. p. 7 - 8.

CENTERS FOR DISEASE CONTROL AND PREVENTION. (2011) Multistate Outbreak of Human Salmonella enteritidis Infections Linked to Alfalfa Sprouts and Spicy Sprout(Final Update: $6^{\text {th }}$ July 2011; cited $10^{\text {th }}$ April, 2019). Available from: http://www.cdc.gov/salmonella/2011/alfalfa-spicy-sprouts-7-6-2011.html. CENTERS FOR DISEASE CONTROL AND PREVENTION. (2012) Multistate Outbreak of E. coli O157:H7 Infections Linked to Romaine Lettuce (Final Update: $23^{\text {rd }}$ March 2012; cited $10^{\text {th }}$ April 2019). Available from: http://www. cdc.gov/ecoli/2011/romaine-lettuce-3-23-12. html.

CENTERS FOR DISEASE CONTROL AND PREVENTION. (2016) Surveillance for Foodborne Disease Outbreaks, United States: 2016, Annual Report. Atlanta, Georgia: U.S. Department of Health and Human Services, CDC, 2018. Available from: https://www.cdc.gov/ fdoss/pdf/2016_FoodBorneOutbreaks_508. pdf.

Cheesbrough, M. (2006) Microbiological Tests: Biochemical Tests to Identify Bacteria. District
Laboratory Practice in Tropical Countries. 2nd ed. Cambridge: Cambridge University Press. p. $62-70$.

Cowan, S. S. T., Feltham, R. K. A., Steel, K. K. T. \& BARrow, G. I. (1993) Cowan and Steel's Manual for the Identification of the Medical Bacteria. 3rd ed. Cambridge, UK: Cambridge University Press.

Davet, P. \& Rouxel, F. (2000) Detection and Isolation of Soil Fungi. USA: Science Publishers, Inc.

De Guisti, M., Aurigema, C., Marinelli, L., Tufi, D., De Medici, D., Di Pasquale, S., De Vito, C. $\&$ Boccia, A. (2010) The evaluation of the microbial safety of fresh ready-to-eat vegetables produced by different technologies in Italy. Journal of Applied Microbiology 109, 996 1006.

Donkor, E. S., Kayang, B. B., Quaye, J., Edoh, D. A. \& Owusu-Okyere, G. (2009) Microbial contamination of green pepper sold in Accra. Ghana Journal of Allied Health Sciences 2, $22-28$.

Donkor, E. S., Lanyo, R., Kayang, B. B., Quaye, J. \& EDOH, D. A (2010) Internalization of microbes in vegetables: Microbial load of Ghanaian vegetables and the relationship with different water sources of irrigation. Pakistan Journal of Biological Sciences 13 (17), 857 - 861.

Ellis, D., Davis, S., Alexiou, H., HandKe, R. \& BartLEY, R. (2007) Descriptions of Medical Fungi. 2nd ed. Adelaide, Australia. Nexus Print Solutions.

Eni, A. O., Oluwawemitan, I. A. \& Solomon, A. U. (2010) Microbial quality of fruits and vegetables sold in Sango, Ota, Nigeria. African Journal of Food Science 4, 291 - 296.

Falomir, M. P., Gozalbo, D. \& Rico, H. (2010) Coliform bacteria in fresh vegetables: from cultivated lands to consumers. In: Current Research, Technology and Education in Topics in Applied Microbiology and Microbial Biotech- 
nology. [A. Mendez-Vilas (Ed)]. FORMATEX Microbiology Series N². Spain, 1175 - 1181.

\section{FOOD AND AGRICULTURE ORGANIZATION/} WORLD HEALTH ORGANIZATION (2014) Fruit and vegetables for health. Report of a joint FAO/WHO Workshop, September 1-3, 2014, Kobe, Japan. Retrieved from http:// www.who.int/dietphysicalactivity/publication/ fruit_vegetables_report.pdf.

GHANA STATISTICAL SERVICE (2010) Population and Housing Census, District Analytical Report. (2010) Retrieved from http://www.statsghana.gov.gh/docfiles/2010_District_Report/ Central/Cape\%20Coast.pdf

Goja, A. M. \& Mahmoud, M. S. O. (2013) Microbial quality of some vegetables sold in ED Dueim Twon, Sudan. Pakistan Journal of Biological Sciences 16 (12), 585 - 588.

HEALTH PROTECTION AGENCY (2009) Guidelines for Assessing the Microbiological Safety of Ready-to-Eat Foods. London.

Keraita, B., Drechsel, P. \& Konradsen, F. (2008) Using on-farm sedimentation ponds to improve microbial quality of irrigation water in urban vegetable farming in Ghana. Water Science and Technology 57 (4), 519 - 525.

Kidd, S., Halliday, C., Alexiou, H. \& Ellis, D. (2016) Descriptions of Medical Fungi. 3rd ed. Adelaide, Australia: Newstyle Printing.

Kuan, C-H., Rukayadi, Y., Ahmad, S. H., Che, J., Thung, T., Premarathne, K., Chang, W-S., Loo, Y., Tan, C-W., Ramzi, O., Fadzil, S., Kuan, C. S., Yeo, S-K., Nishibuchi, M., \& RAdU, S. (2017) Comparison of the microbiological quality and safety between conventional and organic vegetables sold in Malaysia. Frontiers in Microbiology 8, 1-10.

Maffei, D. F., Silveira, N. F. A. \& Catanozi, M. P. L. M. (2013) Microbiological quality of organic and conventional vegetables sold in Brazil. Food Control 29, 226 - 230.
Mensah, P., Armar-Klemesu, M., Hammond, A. S., Haruna, A. \& Nyarko, R. (2001) Bacterial contaminants in lettuce, tomatoes, beef and goat meat from metropolitan Accra. Ghana Medical Journal 35, 1 - 6 .

Obeng, A. S., Ayeh-Kumi, P. F., Kwakye-Nuako, A. G. \& Asmah, R. H., (2007) Pathogenic parasitic microbes associated with fresh vegetables consumed in Accra. Ghana Journal of Allied Health Sciences 1, 11 - 15.

Ofor, M. O., Okorie, V. C., Ibeawuchi, I. I., Ihejirika, G. O., Obilo, O. P. \& Dialoke, S. A. (2009) Microbial Contaminants in Fresh Tomato Wash Water and Food Safety Considerations in South-Eastern Nigeria. Life Science Journal $1,80-82$.

OLAimat, A. N. \& HOlLEY, R. A. (2012) Factors influencing the microbial safety of fresh produce: a review. Food Microbiology 32, 1 - 19.

Olayemi, A. B. (2007) Microbiological hazards associated with agricultural utilization of urban polluted river water. International Journal of Environmental Health Research 7 (2), 149 154.

Omemu, A. M. \& Bankole, M. O. (2005) Ready-toeat (RTE) vegetable salad: effect of washing and storage temperature on the microbial quality and shelf-life. In: Microbes as Agents of Sustainable Development. 29th Annual Conference \& General Meeting of the Nigerian Society for Microbiology UNAAB, Abeokuta 6-10th November 2005 p. 28.

PitT, J. I., \& Hocking, A. D. (2009) Fungi and Food Spoilage. 3rd ed. New York: Springer.

RafiI, F. (2014) Serratia. In: Encyclopedia of Food Microbiology. 2nd ed. Volume 3. [CA Batt, ML Tortorello (Eds)]. Academic Press. pp 371 -375 .

Ray, B. \& Bhunia, A. K. (2007) Fundamental Food Microbiology. 4th ed. CRC Press, USA. p 492. 
Scallan, E., Hoeskstra, R. M., Angulo, F. J., Tauxe, R. V. \& Hoekstra, R. M. (2011) Foodborne illness acquired in the United States - major pathogens. Emerging Infectious Diseases 17 (1), $7-15$.

Sikora, E. J., Bruton, B. D., Wayadande, A. C. \& Fletcher, J. (2012) First report of the Cucurbit Yellow Vine disease caused by Serratia marcescens in watermelon and yellow squash in Alabama. APS Publications 96 (5), 761.

Sivapalasingam, S., Friedman, C. R., Cohen, L. \& TAuXe, R. V. (2004) Fresh produce: A growing cause of outbreaks of foodborne illness in the United States, 1973 through 1997. Journal of Food Protection 67 (10), 2342 - 2353.

Solomon, E. B., Yaron, S. \& Mathews, K. R. (2002) Transmission of Escherichia coli O157:H7 from contaminated manure and irrigation water to lettuce plant tissue and its subsequent internalization. Applied and Environmental Microbiology 68, 397 - 400 .

TAmbeKar, D. H. \& Mundhada, R. H. (2006) Bacteriological quality of salad vegetables sold in Amravati City (India). Journal of Biological Sciences 6 (1), $28-30$.

Uzeh, R. E., Alade, F. A. \& Bankole, M. (2009) The microbial quality of prepacked mixed vegetable salad in some retail outlets in Lagos, $\mathrm{Ni}$ geria. African Journal of Food Science 3 (9), $270-272$.

Wachtel, M. R., Whitehand, L. C. \& Mandrell, R. E. (2002a) Association of Escherichia coli O157:H7 with preharvest leaf lettuce upon ex- posure to contaminated irrigation water. Journal of Food Protection 65, 18 - 25.

Wachtel, M. R., Whitehand, L. C. \& Mandrell, R. E. (2002b) Prevalence of Escherichia coli associated with cabbage crop inadvertently irrigated with partially treated sewage wastewater. Journal of Food Protection 65, 471 - 475.

Watanabe, T. (2010) Pictorial Atlas of Soil and Seed Fungi; Morphologies of Cultured Fungi and Key to Species. 3rd ed. New York: CRC Press.

WORLD HEALTH ORGANIZATION (2015) WHO estimates of the global burden of foodborne diseases. A report by the Foodborne Disease Burden Epidemiology Reference Group 20072015. Geneva, Switzerland.

Yafetto, L., Adator, E. H., Ebuako, A. A., Ekloh, E. \& Afeti, F. Y. (2019) Microbial quality of raw beef and chevon from selected markets in Cape Coast, Ghana. Journal of Biology and Life Science 10 (1), 78 - 97.

Yeboah-Manu, D., Kpeli, G., Akyeh, M. \& Bimi, L. (2010) Bacteriological quality of ready-to-eat foods sold on and around University of Ghana campus. Research Journal of Microbiology 5 (2), $130-136$.

Yeleliere, E., Cobbina, S. J. \& Abubakari, Z. I. (2017) Review of microbial food contamination and food hygiene in selected capital cities in Ghana. Cogent Food and Agriculture 3 (1), doi: 10.1080/23311932.2017.1395102.

Received 03 Oct 19; revised 9 Dec 19. 